\title{
Caregiver-Assisted Training
}

National Cancer Institute

\section{Source}

National Cancer Institute. Caregiver-Assisted Training. NCI Thesaurus. Code C116530.

Any focused education provided to a caregiver. 